\title{
Separating leaves from browse for use in nutritional studies with herbivores
}

\author{
J.F. GALLAGHER, T.G. BARNES, AND L.W. VARNER
}

\begin{abstract}
A technique has been developed that facilitates removal of green leafy material from stems of shrub species using a thresher. Use of this technique makes possible the rapid removal of leaves from woody species that would otherwise require excessive hand labor.

Key Words: sampling, feeding trials, brush collection, white-tailed deer

Nutritional studies of white-tailed deer and other ungulates have largely been conducted using pelleted rations or natural forages that are easily collected such as aspen (Populus spp.), cedar (Thuja

Authors are graduate students, Department of Wildlife and Fisheries Sciences,
\end{abstract}

occidentalis), alfalfa (Medicago sativa), and grasses (Ullrey et al. 1964, Ullrey et al. 1967, Ullrey et al. 1968, Mautz and Petrides 1971, Robbins et al. 1975, Ullrey et al. 1987). To date, few studies have been conducted with woody plants because of the time necessary to collect sufficient forage to maintain the animals for a period of 10 to 14 days. This is especially true when the leaves are small or surrounded by thorns. We developed a technique which allows large quantities of green leafy material to be separated from shrub stems in a relatively short period of time.

\section{Methods}

Samples of brush species known to be eaten by deer (Varner and Blankenship 1987) were collected about $15 \mathrm{~km}$ southwest of Uvalde, Texas. Cenizo (Leucophyllum frutescens) was collected by hand, grasping each branch approximately $15 \mathrm{~cm}$ from the end and stripping the leaves in a single pull. Guajillo (Acacia berlandieri) stems were clipped using small clippers and leaves were removed by JOURNAL OF RANGE MANAGEMENT 41(6), November 1988 \footnotetext{
Texas A\&M University, College Station, Texas 77843; and associate professor, Texas Ariction, Uvalde, Texas 78801

the Caesar Klebers program in Wildlife Ecology machine. This study was funded by Wildlife Foundation Texas Agricultural Experiment Station, and Waty, Manuscript accepted 14 June 1988. 
hand. Blackbrush (Acacia rigidula), brazil (Condalia obovata), and guayacan (Porlieria angustifolia) stems were clipped in the field using small hand clippers.

Approximately $100 \mathrm{~kg}$ of stems less than $20 \mathrm{~mm}$ in diameter were collected and transported daily to the Texas Agricultural Experiment Station located in Uvalde, Texas, for threshing.

Fresh material was then fed into a Vogel Nursery Thresher (Fig. 1) ${ }^{1}$ that separated the leaves from stems. The thresher, which is normally used to thresh small grains, is an overshot spiked cylinder and concave type harvester. The cylinder is constructed of $30-\mathrm{cm}$ steel pipe with 10 rows of heavyduty alternating teeth. The concave is constructed of 6-mm steel plate with 6 rows of teeth extending approximately $5-\mathrm{cm}$ from the surface. The final separation was achieved by the movement of materials across the shaker pan. Forced air from the blower discharged leaves forward and allowed the stems to drop in front of the tail chute. The blower fan speed was adjusted to vary the amount of forced air passing across the plant material which allowed control over the distance the leaves were blown.

To catch leaves, a $3 \times 4-\mathrm{m}$ plastic tarp was suspended approximately $1-\mathrm{m}$ from the tail chute opening at the same height as the thresher opening. Stems dropped to floor in front of the tarp. Leaves and a small amount of stems were then collected in alumi-

\section{${ }^{\top}$ Manufactured by Bill's Welding, Pullman, Washington.}

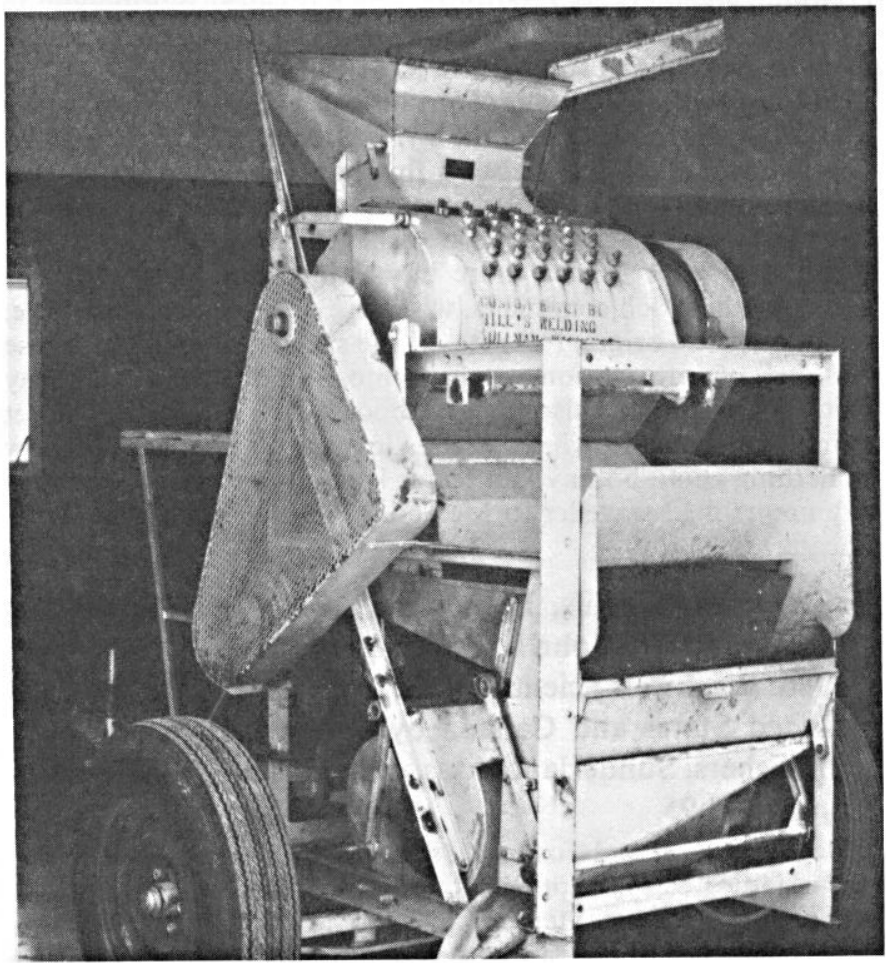

num pans and subsequently separated from any remaining woody materials by sifting through $6-$ or $12-\mathrm{mm}$ hardware cloth screens, depending on leaf size.

\section{Results and Discussion}

Blackbrush is characterized by small compound leaves surrounded by large thorns. Brazil and guayacan are characterized by a complex multistemmed growth form. Both conditions make it difficult and time consuming to remove leaves by hand. The threshing technique allowed us to collect and process enough forage to feed 1 deer (1,600 grams as fed) one day in one-half to one manhour, including time for clipping, threshing, and sifting. We estimate that manual separation of blackbrush leaves would require 6 to 7 man-hours per deer/day. By comparison, cenizo and guajillo, both of which are relatively easy to collect without threshing because of lack of thorns or complex branches, still required over 2.0 man-hours to feed each deer/day.

The technique appears to work well on species with small leaves or single stems. Species with large leaves did not sift away from stems as well, however. Multistemmed species such as brazil were more difficult to thresh, especially if there was abundant terminal growth. Separation of leaves from stems was improved if the material was frozen before threshing.

This technique does have a tendency to select for older, more mature leaves which are smaller and sift easier. The thresher did not remove leaves from the stems of young succulent growth with the same efficiency as from mature growth since stems from new growth are more flexible and less brittle than mature growth.

This technique enabled researchers to collect large amounts of browse material in a short period of time. The final product was largely leaves with relatively little stem material.

\section{Literature Cited}

Mautz, W.W., and G.A. Petrides. 1971. Food passage rate in the whitetailed deer. J. Wildl. Manage. 35:723-731.

Robbins, C.T., P.J. Van Soest, W.W. Mautz, and A.N. Moen. 1975. Feed analysis and digestion with reference to white-tailed deer. J. Wildl. Manage. 39:67-79.

Ullrey, D.E., J.T. Nellist, J.P. Duvendeck, P.A. Whetter, and L.D. Fay. 1987. Digestibility of vegetative rye for white-tailed deer. J. Wildl. Manage. 51:51-53.

Ullrey, E.D., W.G. Youatt, H.E. Johnson, P.K. Ku, and L.D. Fay. 1964. Digestibility of cedar and aspen browse for the white-tailed deer. J. Wildl. Manage. 28:791-797.

Ullrey, D.E., W.G. Youatt, L.D. Fay, and B.E. Brent. 1967. Digestibility of cedar and jack pine browse for the white-tailed deer. J. Wildl. Manage. $31: 448-454$.

Ullrey, D.E., W.G. Youatt, L.D. Fay, B.E. Brent, and K.E. Kemp. 1968. Digestibility of cedar and balsam fir browse for the white-tailed deer. J. Wildl. Manage. 32:162-171.

Varner, L.W., and L.H. Blankenship. 1987. South Texas shrubs: Nutritive value and utilization by herbivores. USDA Forest Serv. Gen. Tech. Rep. INT-222. $179 \mathrm{p}$.

Fig. 1. Vogel Nursery Thresher used to remove leaves from woody stems. 